\title{
A Theoretical Analysis of the Law on Sedition in India
}

\author{
Aishwarya Narayanan*
}

\begin{abstract}
The law on sedition in India has been employed as a tool of harassment to curb free speech. This has resulted in widespread demands to repeal the provisions regarding sedition as it is seen as an archaic law that was meant to serve the colonial interests. In this paper, the researcher explores the law on sedition under section 124A of the Indian Penal Code, 1860. The researcher seeks to propose an amendment to section 124A, by devising Austin's Speech Acts Theory, Sorial's exposition based on Austin's theory and by accommodating the prevalent judicial interpretation into the existing provision.
\end{abstract}

Keywords: Free Speech, Judicial Interpretation, Section 124A, Sedition, Speech Acts Theory.

\section{Introduction}

"Guess what's common between a high profile tribal rights activist, ${ }^{1}$ a renowned Indian author, ${ }^{2}$ a talented cartoonist ${ }^{3}$ and a

* Third Year, B.A. LL.B.(Hons.), National Academy of Legal Studies and Research, Hyderabad; narayanan.aishwarya94@gmail.com

1 C. Sathyamala, Binayak Sen: Refining Health Care in an Unjust Society, 4(3) INDIAN J. MED. ETH. 104, 104-105 (2007), (Dr.Binayak Sen, the General Secretary of P.U.C.L., was arrested in May 2007 for allegedly acting as a courier for a jailed Maoist leader in Chhattisgarh).

2 Press Trust of India, Sedition Case Registered Against Arundhati Roy, Geelani, NDTV, Nov. 29, 2010, http://www.ndtv.com/ article/ india/ sedition-case-registered-against-arundhati-roy-geelani-69431, 
group of Kashmiri students cheering for Pakistan in a cricket match?" 4 All of them have been innocent victims of the supposedly 'draconian' law on sedition in India. The manner in which the law relating to sedition has been misused of late has brought it sharply into the limelight for all the wrong reasons. The provisions that deal with sedition have been subject to rampant scrutiny and public criticism, with some advocating a complete repeal of the same. In this light, it becomes important to carefully study the law relating to sedition and examine its pros and cons before jumping to arbitrary conclusions. In this paper, an attempt is undertaken to make an informed study of the law of sedition and suggest a way forward on the basis of the information collected.

The paper has been divided into four parts. The first part is a general introduction to the law of sedition in India, the relevant provision and its scope. The second part deals with the case against sedition and presents arguments which are commonly cited against the law of sedition. It also examines the manner in which the same has been interpreted in a restricted sense by the judiciary. The third part draws upon Austin's Speech Acts Theory to determine the nature of seditious harm and argues how the very nature of the act makes it one befitting the status of an offence rather than reiterating the conventional arguments for sedition. The last part includes the conclusion and suggestions. On the basis of the arguments presented, it offers a modified version of the sedition

(Arundhati Roy and Hurriyat leader Syed Ali Shah Geelani were arrested for allegedly making anti-India speeches at a conference on "Azadi - the Only Way" in 2010).

${ }^{3}$ Special Correspondent, Mumbai Police Arrest Cartoonist, Slap Sedition, Cybercrime Charges On Him, THE HINDU, Sept. 10, 2012, http://www.thehindu.com/news/national/mumbai-police-arrestcartoonist-slap-sedition-cybercrime-charges-on-him/article3877809.ece, (Aseem Trivedi was arrested for making and publishing seditious cartoons as part of the India against Corruption movement in 2012).

${ }^{4}$ Dean Nelson, Indian Kashmiri Cricket Fans to be Charged for Cheering Pakistan, Mar. 25, 2014, THE TELEGRAPH, http://www.telegraph.co.uk/news/worldnews/asia/india/10678163/I ndian-Kashmiri-cricket-fans-to-be-charged-for-cheering-Pakistan.html, (A group of Kashmiri students was arrested in Meerut for cheering for Pakistan in a televised Asia Cup cricket match in May 2014). 
law thereby striking a fine balance between the proponents and opponents of the same.

\section{Law on Sedition in India}

Law relating to sedition in India is correctly viewed as a relic of the British rule, a constant reminder of that inglorious period of our past. It has been aptly quoted that, "the sedition provisions are a prime example of the manner in which the imperial powers of a foreign government are transformed into the normal powers of an independent regime." 5 The law against sedition is primarily contained in section 124A of the Indian Penal Code, 1860 (IPC). It is important to note that the word 'sedition' has not been used anywhere in the Constitution; it merely forms a marginal note to the section in the IPC. ${ }^{6}$ It was also removed as one of the grounds for nullification of laws under Article 13(2) of the Constitution. ${ }^{7}$ Macaulay's Draft Penal Code contained the offence of sedition in Section 113; however, the same was dropped from the final version adopted in 1860.8 Section 124A was subsequently inserted in 1870 when the British government felt the need for a specific provision to deal with the offence in light of the increasing 'Wahabi' revolts. ${ }^{9}$ The provision as it stands today finds its place in Chapter VI of the IPC which deals with 'Offences against the State.'10

5 Siddharth Narrain, 'Disaffection' and the Law: The Chilling Effect of Sedition Laws in India, 46(8) ECON. POLIT. WKLy 33, 33-37 (Feb. 19, 2011), available at http://jmi.ac.in/upload/menuupload/16_ccmg_epwsedition.pdf.

6 Ratanlal \& DhiRajlal, The Indian Penal Code 534 (Justice Y.V. Chardrachud \& V.R. Manohar eds., 31st ed. 2006).

$7 \mathrm{Id}$.

8 CENTRE FOR the STUdy of SOCIAL EXCLUSION AND INCLUSive POLICY, NATIONAL LAW SCHOOL OF INDIA UNIVERSITY, E ALTERNATIVE LAW FORUM, SEDition LAWS \& THE DEATH OF FREE SPEECH IN INDIA 9 (Chandan Gowda ed, 1st ed. 2011), available at https://www.nls.ac.in/resources/csseip/Files/SeditionLaws_cover_Fi nal.pdf.

9 Narrain, supra note 5 at 33.

${ }^{10}$ (It is interesting to note that the provision relating to sedition has been placed in Chapter VI rather than Chapter VIII of the IPC which deals with Offences against Public Tranquillity. This clearly indicates that the 


\section{The Section and its Scope}

As already mentioned, section $124 \mathrm{~A}$ of the IPC 11 is the primary source of sedition law in India. On a plain reading of the section, one can identify the following four elements that are required for it to be invoked:

I. A person must bring, or attempt to bring into hatred or contempt, or excite or attempt to excite disaffection;

II. Such disaffection should be targeted against the government established by law in India;

III. The said disaffection may be caused by words (written or spoken), or by signs, or by visible representation, or otherwise; and

IV. The said words must not amount to a fair criticism of policy or administrative action undertaken by the government (which are protected by the explanations to the section).

It is apparent that the section has been couched in the broadest possible language so as to accord it with a wide ranging scope. Sedition is an intention driven offence. While actual disturbance is not necessary to be proved to establish an offence under section $124 \mathrm{~A}$, it is necessary to prove that the impugned words were uttered with the intention of inciting hatred; a mere tendency to incite hatred would not suffice. ${ }^{12}$ Such intention must be gauged by the standards of a reasonable man. ${ }^{13}$ This section has historically been employed against prominent leaders of the national movement like Balgangadhar Tilak, Mahatma Gandhi and Annie Besant. ${ }^{14}$ However, as shall be subsequently discussed, the courts have increasingly moved away from a draconian interpretation of the law and construed this Section in narrow terms to try and

section is intended to criminalize mere words regardless of any consequent action. Disturbance to public order is implicitly not intended to be included as a necessary ingredient of the section. However, this view has been altered by the Supreme Court as discussed later).

${ }^{11}$ PEN. CODE $§ 124$ A.

${ }^{12}$ RATANLAL, supra note 6 at 356 .

${ }^{13} I d$ at 356.

${ }^{14}$ ALTERNATIVE LAW FORUM, BANGALORE, supra note 8 at 10-14. 
prevent the misuse of excessively arbitrary and discretionary power by the authorities.

\section{The CAse Against Sedition}

"Section 124A, under which I am happily charged is perhaps the prince among the political sections of the Indian Penal Code designed to suppress the liberty of the citizen". ${ }^{15}$

Mahatma Gandhi, March 18, 1922

The aforementioned quote succinctly reduces the entire argument against sedition into a single line. The case against sedition is one that has been argued on multiple prongs. Most of the arguments against sedition which are based on freedom of speech, superiority of the state, ineffective implementation etc have been reiterated time and again and therefore the researcher does not intend to deal them in detail. However, a detailed discussion on the provision regarding sedition as interpreted by the Supreme Court is undertaken, thereby reflecting the judicial hesitance in employing the section.

\section{The Free Speech Argument}

The most often cited argument against sedition finds its basis in the principle of free speech. The Constitution of India guarantees the freedom of speech and expression under Article 19(1)(a). ${ }^{16}$ The constitutionality of section124A has often been challenged in court on the ground that the said provision is violative of the fundamental right to freedom of expression and is therefore ultra vires the Constitution. However, the matter has emphatically been settled by the Supreme Court in 1962 where it held that section 124A was not unconstitutional, subject to certain limitations which shall be discussed later. ${ }^{17}$ However, the opponents of the law

${ }^{15} \mathrm{Id}$ at 14 (Mahatma Gandhi, during his famous sedition trial of 1922).

${ }^{16}$ (What is often ignored is the fact that the right is not absolute and is subject to the limitations contained in Article 19(2) which allows the State to impose reasonable restrictions on the freedom of speech in certain situations).

17Kedar Nath Singh v. State of Bihar, 1962 S.C.R. Supl. (2) 769. 
relating to sedition continue to use the free speech argument as the foundation of their dissent on the sedition law.

The free speech argument is closely linked with India's democratic set up. It is argued that India being a democracy, the right to air one's views and opinions about the Government is not just desirable, but is necessary for its proper functioning. ${ }^{18}$ Active public participation forms the backbone of a functional democracy and any curtailment of this right of participation is necessarily frowned upon. It can further be argued that a provision for sedition which necessarily places the government at a higher pedestal than the citizens has no place in a democracy where the people themselves are the true rulers, or at least have the power to choose their own rulers.

\section{The Judicial View on Sedition}

Since its establishment in 1950, the Supreme Court of India has only dealt with thirty eight cases that refer to sedition and has pronounced only six judgements wherein it has extensively discussed the offence. ${ }^{19}$ This naturally leads to two inferences: (1) the offence of sedition is not one that has been misused to the extent to which it is hyped; and (2) even when the courts have dealt with the issue of sedition, they have done so in a rather narrow and restricted manner. A very brief overview of the approach adopted by the Supreme Court in dealing with this issue is given below.

The courts in the pre independence era had interpreted sedition to give the term 'disaffection' a very wide connotation while holding that for the offence of sedition to be committed, the amount of disaffection and the causing of actual disturbance were

${ }^{18}$ ALTERNATIVE LAW FORUM, supra note 8 at 15-18 (Similar views were expressed by the framers of the Constitution in the Constituent Assembly).

${ }^{19}$ Madhu Limaye v. S.D.M., Monghyr \& Ors. (1970) 3 S.C.C. 746; Balwant Singh v. State of Punjab, (2005) 3 S.C.C. 214; Bilal Ahmed Kaloo v. State of A.P., (1997) 7 S.C.C. 431, Kedar Nath Singh v. State of Bihar, 1962 S.C.R. Supl. (2) 769, Romesh Thapar v. State of Madras, A.I.R. 1950 S.C. 124, Brij Bhushan \& Anr v. State of Delhi, A.I.R. 1950 S.C. 129. 
immaterial20. In the first case on sedition that was decided by the Supreme Court, Romesh Thapar v. State of Madras ${ }^{21}$, section 124A of the IPC was declared unconstitutional since it falls outside the scope of Article 19(2).22

In Kedar Nath Singh v. State of Bihar, ${ }^{23}$ the Supreme Court upheld the constitutional validity of section $124 \mathrm{~A}$, while at the same time curtailing its meaning and limiting its application to acts that clearly involved a tendency to create public disorder. Such a restricted understanding of the term has been upheld and adopted in the subsequent decisions also. ${ }^{24}$ The Court has gone as far as to state that, "the objects of sedition generally are to induce discontent and insurrection, and stir up opposition to the Government, and bring the administration of justice into contempt; and the very tendency of sedition is to incite the people to insurrection and rebellion." 25

The approach of the court has indicated its reluctance to accord a wide magnitude to the offence of sedition and has instead restricted it to the narrowest margin possible. However, the recent arrests of Aseem Trivedi, certain Kashmiri students and several others, display a glaring disconnection between the established position of the law and its actual implementation. ${ }^{26}$ The discord between the higher judiciary, the lower judiciary and the police has resulted in a state of affairs that makes a mockery of the law as it presently stands.

${ }^{20}$ Alternative LAW FORUM, supra note 8 at 12 (Sedition Trial of Bal Gangadhar Tilak in 1908).

${ }^{21}$ Romesh Thapar, A.I.R. 1950 S.C. 124.

${ }^{22}$ (It must be noted that at this time Article 19(2) included only 'security of state' and not 'public order' as a ground to justify restriction of speech. In order to rectify this, the First Amendment to the Constitution was enacted in 1951 to include 'public order' as one of the grounds for restricting the freedom of speech under Article 19(2)).

${ }^{23}$ Kedar Nath Singh, 1962 S.C.R. Supl. (2) 769.

${ }^{24}$ Madhu Limaye v. S.D.M., Monghyr \& Ors. (1970) 3 S.C.C. 746; Balwant Singh v. State of Punjab, (2005) 3 S.C.C. 214; Bilal Ahmed Kaloo v. State of A.P., (1997) 7 S.C.C. 431.

${ }^{25}$ Nazir Khan v. State of Delhi, (2003) 8 S.C.C. 461.

${ }^{26}$ ALTERNATIVE LAW FORUM, supra note 8 at 29. 


\section{THE CASE FOR SEDITION}

"Words are, of course, the most powerful drug used by mankind". 27

There is perhaps no better way to argue the case for sedition than to quote the above words. While making a case against sedition, the researcher highlighted some of the common arguments that are presented by the opponents of the law relating to sedition and also looked into the judicial history of the same in India. The researcher, in this paper refrains from following a similar approach to make a case for sedition and providing counter arguments to the points raised. This is because the arguments regarding imposition of reasonable restrictions on the freedom of speech, the constitutionality of the law on sedition and the natural superiority of the State on the basis of the Social Contract Theory ${ }^{28}$ have already been the subject of widespread discussion. Therefore, the researcher intends to address the issues through another approach.

In this regard, the paper focuses on the nature of seditious harm and the inherently dangerous nature of words themselves rather than the concept of rights and principles. The author employs J.L. Austin's Speech Acts Theory ${ }^{29}$ to contend that certain types of words are dangerous in themselves and are therefore liable to be punished without considering their consequences. The research also extensively draws upon the works of Sarah Sorial ${ }^{30}$ to discuss the nature of seditious harm. In order to fully comprehend the

27 Rudyard Kipling, Surgeons and the Soul inA WORD OF BOOKS available at https://ebooks.adelaide.edu.au/k/kipling/rudyard/words/chapter23. html (last visited Dec. 22, 2014).

28 (Hobbes, Locke and Rousseau each propounded a different version of the Social Contract Theory; however, in each case the essence of the theory is the formation of a State which would be superior to the citizens - irrespective of whether it is in the form of a leviathan, a representative government or sovereign).

29 J. L. Austin, How TO DO THINGS WiTH WORDS (Harvard University Press, 1st ed., 1962).

30 Sarah Sorial, Can Saying Something Make it So? The Nature of Seditious Harm 29 LAW \& PHILOSOPHY 273-305 (2010). 
arguments raised in this paper, it is necessary to briefly review Austin's Speech Acts Theory and Sorial's argument.

\section{Austin's Speech Acts Theory}

J.L. Austin was a twentieth century British philosopher of language who is credited to be the developer of the Theory of Speech Acts. His book, 'How to do Things with Words' (1962) is considered to be the origin of the Speech Acts Theory. Prior to Austin, linguistic philosophers had directed their attention exclusively to linguistic acts that had truth value (i.e., statements, declarations etc.). This centred around the division between proper names and functional expressions developed by Gottlob Frege. However, problems raised by attempts at classifying sentences into either category resulted in the development of the notion of truth value. Thus, every sentence, whether in the form of a declaration, or in the form of predicate expressions used to denote classes of objects, is used to denote some specified object in the form of its truth value i.e., the true or the false. Thus, the statement 'Bangalore is a city' is necessarily true while 'Mount Everest is a city' is necessarily false. Every statement therefore has an inherent truth value. ${ }^{31}$

Austin's Theory emerged from a rejection of both the meaningful/meaningless divide (depending upon whether the utterance in itself has any meaning) and the constative/performative divide (between statements that are merely statements and those that constitute acts) prevalent in the linguistic theory. Instead, Austin proposed that all statements have both a constative as well as a performative aspect. Therefore, each statement is a statement like a declaration and is also intended to perform a particular act.

The basic theme underlying the theory is that not only do statements describe things or state facts; they also perform a certain kind of action by themselves. He defined 'speech acts' as those units of speech that have both a performative and a constative

31Truth Values, Stanford Encyclopaedia of Philosophy available at http:/ / plato.stanford.edu/entries/truth-values/\#1 (last visited Feb. 14, 2015). 
dimension. ${ }^{32}$ Austin further proposed three categories of speech acts; locutionary, illocutionary and perlocutionary. The speech acts of making a meaningful utterance by vocalizing the sentence is a locutionary act. A locutionary act consists of three components. It involves the production of some sounds or noises (phonetic act). These noises are intentionally produced as belonging to a certain language and following certain grammar (phatic act). This utterance which has been intentionally produced in a certain order conveys certain messages (rhetic act). Performing all the three together constitutes a locutionary act. ${ }^{33}$

An illocutionary act is one wherein the speaker actually performs an act in uttering the sentence. Every statement must be taken in a certain way, i.e., it has got an illocutionary force and uttering such a statement is an illocutionary act. For example, by uttering the words 'I apologize', the speaker intends to perform the act of apologizing and the phrase itself must be taken as an apology. ${ }^{34}$

A perlocutionary act is one wherein the speaker tries to accomplish an act by uttering it. The speaker tries to produce certain consequential effects upon the feelings, thoughts and actions of the audience. Therein, he performs a perlocutionary act. ${ }^{35}$ Persuading, convincing or getting people to do something are examples of perlocutionary acts. All three categories are often involved in the same speech act. What category a particular speech acts falls under depends upon the perspective from which the act is viewed. ${ }^{36}$

Austin further presented five general classes of illocutionary forces: verdictives, exercitives, commissives, behabitives, and expositives. ${ }^{37}$ Verdictives are related to the act of pronouncing a judgement or a verdict, most commonly associated with juries or

${ }^{32}$ Kevin Halion, Deconstruction and Speech Act Theory: A Defence of the

Distinction between Normal and Parasitic Speech Acts, E-ANGLAIS, available at http:/ / www.e-anglais.com/thesis.html (last visited Jan. 7, 2015).

${ }^{33} \mathrm{Id}$.

${ }^{34}$ Halion, supra note 32.

35 Halion, supra note 32.

36 Halion, supra note 32.

${ }^{37}$ Yoshitake Masaki, Critique of J.L. Austin's Speech Act Theory: Decentralization of the Speaker-Centred Meaning in Communication, 2 KYUSHU COMMUNICATION STUDIES 30, 27-43 (2004). 
judges. Exercitives are related to executions of right or authority. Statements ordering action fall under this type. Commissives are those by which the speaker is obliged to do something by uttering a statement. A promise is a typical example of this type. Behabitives are related to attitudes or social behaviour. The act of congratulating falls under this type. Expositives are mostly clarificatory in nature, explaining to the listener how a particular statement fits the conversation or the situation. Words like 'describe' and 'explain' are typically used in this context. ${ }^{38}$

Moreover, performatory devices are a special kind of illocutionary devices, ${ }^{39}$ i.e., they are the kind of words which when spoken constitute the act itself. For example, the utterance of the words 'I do' by the bride and the groom during a wedding ceremony constitutes the very act of getting married. The statement is not merely descriptive or normative but performative in nature. Performatives are merely a type of illocutionary acts which were initially used to connote statements that were explicitly acts. Thus, 'I promise to be there at 5 ' would be performative in the sense of making a promise while ' $I$ will be there at 5 ' would not. Later developments resulted in the classification of performatives as explicit and implicit, thus brining both the above sentences within the ambit of performatives. Performatives in this sense are just a category or subtype of illocutionary acts.

Austin's Speech Acts Theory has come under considerable scrutiny and criticism. The theory has been modified by Searle to replace locutionary acts with propositional acts which are basically incorporated within illocutionary acts. ${ }^{40}$ In this sense, Searle further strengthens the Speech Acts Theory by accepting and further proposing that in fact all statements do constitute acts of some sort.

Cohen challenged Austin's Theory by questioning the very existence of illocutionary forces. He claimed that statements by themselves have some meaning and it is this meaning that gives them force. There is no need to have force as a separate component as it is intrinsically derived from the meaning of the words

\footnotetext{
38 Id at 30.

${ }^{39}$ Halion, supra note 32.

${ }^{40} \mathrm{Id}$.
} 
themselves. ${ }^{41}$ Even this argument does little to pose a substantive challenge to the proposition that words have a performative aspect and can constitute acts. It merely questions the source of the force which grants words with the status of acts. This source is irrelevant to the determination of whether the statement in fact constitutes an act, and to that extent, Austin's Theory stands unchallenged. His Speech Acts Theory marked a turning point in modern day linguistics by shifting the focus of language philosophers from the truth value of statements to the performative value of words.

\section{The Nature of Seditious Harm}

Sorial uses Austin's Speech Acts Theory to demonstrate that certain words are inherently dangerous and their very utterance may give rise to harm. She assumes that some words do constitute acts in themselves. She analyzes the concept of illocutionary acts and concludes that, for illocutionary acts to have the desired effect, they must be uttered with the intention to do the said act, 42 and that the words must be spoken by the appropriate person in the appropriate context. ${ }^{43}$ These two criteria namely speaker and intent lend the words their illocutionary force. She further notes that verdictive and exercitive acts have the additional qualities of being 'obligation enacting' 44 and enacting the 'permissibility conditions' necessary for inflicting violence. 45 The very nature of these acts as giving judgements or commands poses a sense of obligation upon the listener and urges him to perform the desired act.

Sorial makes these observations in the context of speeches by authoritative religious leaders and clerics that incite violence. In such cases, she argues that the speech itself constitutes the act as it exhibits the aforementioned qualities. She further contends that

41Stanford Encyclopaedia of Philosophy, Speech Acts, (Jul. 03, 2007) http://plato.stanford.edu/entries/speech-acts/.

${ }^{42} \mathrm{R}$. Langton, Speech Acts and Unspeakable Acts, 22 PHILOSOPHY AND PUBLIC AFFAIRS 305, 293-330 (1993).

43Sorial, supra note 30 at 290.

${ }^{44}$ Ishani Maitra and Mary Kate McGowan, The Limits of Free Speech: Pornography and the Question of Coverage, 13(1) LEGAL THEORY 45, 41-68 (2007). 
such types of speech acts; verdictive and exercitive speech acts that enact the permissibility conditions for violence by altering norms and imposing obligations should not be protected by a free speech principle irrespective of whether any actual violence occurs. ${ }^{46}$ She, thus, advocates that, in cases relating to religious incitement of violence, the speech itself should be punishable, provided that it is uttered by a person in authority and is understood in context. ${ }^{47}$

\section{The Need to Punish Sedition}

The author argues in natural continuation of Sorial's argument by extending it to other persons in authority who may exercise considerable political and/or public influence. The author bases her argument on the premise that it is important to retain sedition as a crime against the State, for the State is the protector of our rights and there can be no substantive rights in the absence of the State. Therefore, destabilizing the State by any means is undesirable and liable to be punished.

According to the author, certain words when spoken by certain persons in particular contexts, do have the authority to incite violence. This is not restricted to merely religious leaders but equally extends to persons who exercise political influence or command the respect of the public in general. Therefore, a call by a well known Naxal leader (either popular or notorious depending upon which side of the battle one supports) instigating a revolution and calling for an overthrowing of the government or by a well known state leader demanding secession from the country is as seditious as a fatwa calling for violence.

The speakers, by virtue of their authority, have the power to influence people, to instigate them to commit mutiny and cause disorder. In such cases, the very utterance of the words constitutes the act of incitement and thereby amounts to the crime of sedition. These acts fall within the category of exercitive acts that enact the permissibility conditions for causing violence. Not only do these words by themselves constitute the act of incitement, they more often than not also have the desired effect of causing incitement.

46Sorial, supra note 30 at 298.

47 Sorial, supra note 30 at 276. 
Thus, the ability of words to cause such effects by their very utterance exposes their intrinsically dangerous character.

The author further contends that such cases fall beyond the protection of free speech not just because of the nature of the words and their tendency to cause violence, but because in such situations, the words themselves constitute the acts and therefore fall outside the purview of the free speech doctrine. The free speech doctrine, as the very name suggests, protects speech and not acts. Speech that amounts to acts is not afforded this protection.

The author finally rests her case upon the inherently dangerous nature of words that lends them susceptible to punishment provided that certain essential prerequisites are fulfilled. The inferences and conclusions drawn on this basis shall be enumerated in the next and final part of the paper.

\section{Conclusion: The Way Forward}

On the basis of the foregoing discussion, it is apparent that there is a real and pressing need to strike an appropriate balance between the views of the proponents and opponents of the law relating to sedition. While the case against sedition has its merits, it is not enough to overwhelm and overrule the case for sedition. In such a situation, the author seeks to propose a middle ground as the way forward; a solution that factors in both the sociological as well as the precedential aspects of the law of sedition. The author is of the view that it is important to retain sedition as an offence but not in its present form.

In light of this, the following modification to the law is suggested. Section 124A should be retained subject to three conditions: first, that, the offender must be in a position of authority (as suggested by Sorial); second, that, the offending words must be understood in context (as suggested by Sorial); and, third, they should have a tendency to actually cause violence or disorder (as held in Kedar Nath Singh).

Thus, the redrafted section 124A would read as follows:

124A. Sedition -- Whoever by words, either spoken or written, or by signs, or by visible representation, 
or otherwise, brings or attempts to bring into hatred or contempt, or excites or attempts to excite disaffection towards, the Government established by law in India, shall be punished with imprisonment for life, to which fine may be added, or with imprisonment which may extend to three years, to which fine may be added, or with fine.

Provided that the offender must be in a position of authority and influence;

Provided further that the offending words or signs or representations must be understood in the relevant context in which they are expressed; and

Provided further that the said expressions must have a tendency to actually cause violence or public disorder.

Explanation 1 - The expression 'disaffection' includes disloyalty and all feelings of enmity.

Explanation 2 - Comments expressing disapprobation of the measures of the Government with a view to obtain their alteration by lawful means, without exciting or attempting to excite hatred, contempt or disaffection, do not constitute an offence under this Section.

Explanation 3 - Comments expressing disapprobation of the administrative or other action of the Government without exciting or attempting to excite hatred, contempt or disaffection, do not constitute an offence under this Section.

While it is important to retain the provisions relating to sedition, it must also be subject to certain statutory safeguards. The researcher opines that such redrafting would provide the most efficient solution to the problem caused by the misuse of sedition law. It is expected that the section in the proposed form would adequately serve this purpose. 